International Journal of Social Sciences and Humanities
Available online at www.sciencescholar.us
Vol. 6 No. 1, April 2022, pages: 23-29
e-ISSN: 2550-7001, p-ISSN: 2550-701X
https://doi.org/10.53730/ijssh.v6n1.3064

\title{
The Urgency of Developing the Capacity Building on Saniri Institution
}

Judy de Fretes a, Sukur Soasiu b, Fatima Suatrat c
Manuscript submitted: 27 November 2021, Manuscript revised: 18 December 2021, Accepted for publication: 09 January 2022

International Journal of Social Sciences and Humanities (C) 2022.

This is an open access article under the CC BY-NC-ND license (https://creativecommons.org/licenses/by-nc-nd/4.0/).

\section{Contents}

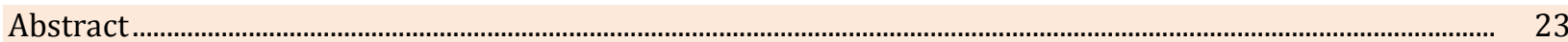

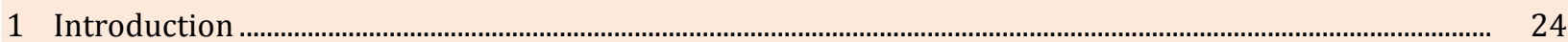

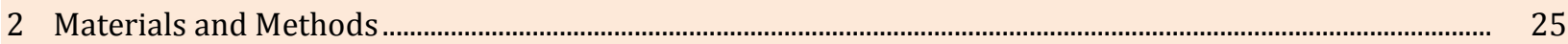

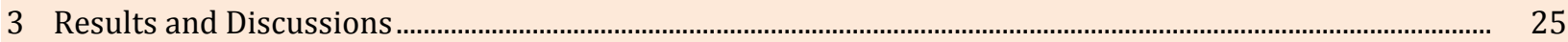

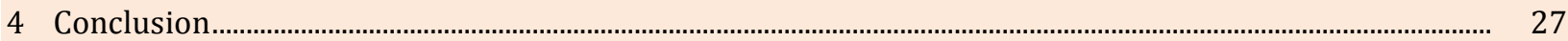

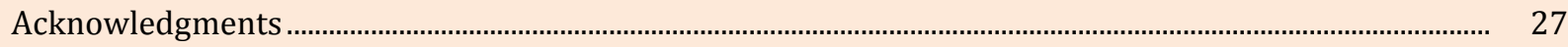

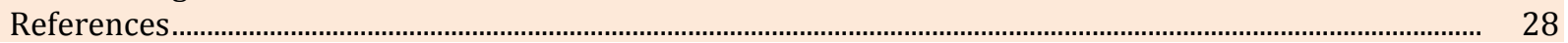

\footnotetext{
a Universitas Pattimura, Indonesia

${ }^{\mathrm{b}}$ Universitas Pattimura, Indonesia

${ }^{\mathrm{c}}$ Universitas Pattimura, Indonesia
} 


\section{Introduction}

The enactment of Law Number 5 of 1979 has weakened the existence of local institutions. One of the traditional institutions that lost its role was the State Saniri because it was replaced by the Village Consultative Body (VCB). Although the village community body (VCB) has legitimacy according to applicable regulations, in indigenous communities or lands, it lacks legitimacy, and this is because the composition of VCB membership is no longer appropriate, such as senior membership which comes from soa heads who are leaders of several clans or fam.

The state sanitation agency then regains the power of law in carrying out its duties and functions as a state government partner. Of course, this is not an easy task. Saniri Negeri is the embodiment of the legislative body in customary lands. Saniri is no different from the Village Representative Body (VRB). The term BPD is used in villages. Meanwhile, in the customary lands in Maluku, in this case, Ambon City, Lease Islands, and Seram Island, some use the term Saniri Negeri, but some use the State Representative Body (SRB) based on Regency/City regulations. The Village Government must be able to oversee community institutions to optimize the village's potential (La Suhu \& Wance, 2019).

In addition, from 2014 until now, the central government has disbursed a reasonably large amount of funds, ranging from 1 to 2 billion, based on village area and population. This fund is intended for village/state infrastructure development, rural/state community empowerment, and village/state government operational costs. Saniri also functions to oversee the use of the budget to prevent misuse of these funds. Of course, this task is also not easy; from the news on television and in newspapers, many village heads, including Maluku, were involved in corruption cases related to the misuse of the Village Fund and Village Fund Budget. This indicates a lack of supervision by the Village Empowerment Agency (VFB) or the Saniri institution (Cramb \& Wills, 1990; Poudel, 2019; Kaliky et al., 2020).

In Negeri Mamala, Leihitu Sub-district, Central Maluku Regency, Saniri Negeri was formed in 2015 with seven representatives from Soa-Soa in Mamala, plus the representation of women and youth that the number of Saniri was seven people. At the beginning of its formation, before carrying out its duties and functions, members of the saniri were given socialization from the district government regarding implementing the duties, functions, and responsibilities of the saniri. It has not been optimally and adequately carrying out its duties and functions (Geiling et al., 2014; Ziphorah, 2014). Saniri did not understand his duties and responsibilities some time ago due to hearing input from people who did not like the current King's leadership, so they wanted to overthrow the current King's leadership and have ended its stewardship this year. Moreover, the members have also been re-elected, and all of them are new people. In Mamala Country, not everyone has the right to become a member of Saniri. Each Soa will meet and appoint one of Soa's children to be a member of the Saniri. In addition, one of the requirements is that he can show his education certificate, at least having a junior high school diploma. Moreover, it was found that in the appointment of Soa's son to become a member of Saniri, it turned out that two people could not show their certificates, so they were both returned to SOA to be chosen by someone else to become a member of Saniri. Financial management in COVID-19 conditions is very different from normal conditions, so the budget prescription is not optimal because the village government is still waiting for guidance from the central government (Tuanaya et al., 2020).

Although the duties, functions, and authorities have been regulated in the Regional Regulation, there are still weaknesses or weaknesses of the state saniri apparatus, including 1) There is intense domination of the leadership of the state government or the King; 2) Lack of competent human resources from state saniri; 3) The weak responsiveness of the country's sanitation to the needs of the people of the country; 4) Lack of knowledge in formulating state regulations, and; 5) Weak ability to innovate for self-development. Thus, it is necessary to strengthen the capacity of sanitation, both individually and institutionally, which is carried out periodically. This study was conducted to analyze the performance of the Saniri, the inhibiting factors, and various strategies that can be taken to strengthen the capacity of the Mamala State Saniri. 


\section{Materials and Methods}

The type of research used is a qualitative research type with descriptive elaboration, namely a study that aims to obtain an overview of whether the State Saniri knows and understands its duties, functions, and responsibilities. According to Bogdan and Taylor in Moleong (2007), qualitative methodology is a research procedure that produces descriptive data in written and spoken words from people and observable behavior (Phillippi \& Lauderdale, 2018; Antin et al., 2015; Morse, 2015; Marshall et al., 2013; Percy et al., 2015; Bengtsson, 2016).

The data collected is the result of the field obtained through primary data collection such as observations, interviews, library research, and secondary data collection such as supporting data obtained from existing archives/documents or written literature closely related to the research title. The research focused on the indicators: (1) performance of the State Saniri of Mamala. (2). Factors hinder the performance of sanitary institutions in Mamala Country. (3). Strategy to strengthen capacity building of sanitary institutions in Mamala Country.

This research will be conducted in Mamala Country, Leihitu District, Central Maluku Regency. Furthermore, this research lasted for one month. This research, which is planned to serve as critical informants, are community members who understand the problem and purpose of the research. Informants selected as key informants from the community included the Mamala State Saniri, Mamala State Government Staff, traditional leaders, the Head of SOA, and community leaders. The field data needed from informants is carried out through the snowball technique to find suitable informants, and research using qualitative methods like this aims to capture information from various sources (Moleong, 2007).

\section{Results and Discussions}

\section{Mamala Country Saniri performance}

State Saniri in customary lands, especially in Central Maluku Regency, is very important. This is because the saniri institution was formed as a partner of the State Government, which has an equal position with the head of the state government (King) in the structure of the state government. According to Moenir (2008), the development of state apparatus or village apparatus can be successful if the organization obtains physical and spiritual satisfaction at the State apparatus or apparatus at all levels, all of which are organizations that can develop forward according to plan. Saniri Negeri has the duties and functions as well as the authority as regulated in the Central Maluku Regency Regional Regulation No. 4 of 2006 :

The duties and functions of the State Saniri are: 1) guarding, nurturing, nurturing, and preserving the customs, customary law, and culture of the community in its living and developing environment; 2) accommodating and channeling the aspirations of the community; 3) stipulating a State Regulation together with the Head of State Administration; 4) supervise and determine the State Revenue and Expenditure Budget. Meanwhile, the authority of the State Saniri are: 1) Discussing the draft of the State Regulation together with the Head of the State Government; 2) Carry out supervision on the implementation of State Regulations and Decrees of the Head of State Government; 3) Propose the appointment and dismissal of the Head of State Government; 4) Forming a committee for the election of the Head of State Government; 5) Explore, accommodate, collect, formulate and channel the aspirations of the community; and 6) Formulate the rules of State Saniri (Merino \& de los Ríos Carmenado, 2012; Suacana \& Suaib, 2016).

When writers refer to the duties, functions, and authorities of the State Saniri institution as regulated in the Central Maluku Regency Regional Regulation No. 4 of 2006, it is certainly not an easy task for Saniri Negeri to be able to carry out its duties and functions and authorities properly. Nevertheless, what happens, the performance of the State Saniri has not been maximized. This can be seen from the many customary lands in Central Maluku Regency that have not had a definitive head of government and are led by an official. Saniri Negeri is not consistent with the rules.

In Regional Regulation No. 4 of 2006, it is clearly stated that the authority and obligation to process the Head of State Government (King) begins with forming an election committee. However, then this process runs slowly and even seems long-winded. One of the reasons is that no State Regulation regulates parental house

Fretes, J. de, Soasiu, S., \& Suatrat, F. (2022). The urgency of developing the capacity building on Saniri institution. International Journal of Social Sciences and Humanities, 6(1), 23-29. https://doi.org/10.53730/ijssh.v6n1.3064 
eyes, so the conflicts among the eyes of the house itself make Saniri not dare to take steps. One of the factors that cause many traditional lands in Central Maluku Regency to not have a State Regulation is the inability of Saniri to make a regional regulation. People who want to be elected as State Saniri must be seen again regarding their human resources, have adequate education, and people who can be assertive (Wickham et al., 2010; Biitir et al., 2017).

In Mamala Country, Saniri Negeri was only inaugurated earlier this year. In the previous period, Saniri Negeri had not shown good performance. Based on the results of interviews with. The Mamala State Secretary, the new Head of Saniri Negeri, and several members of the State Saniri, it was found that there was a change in the Mamala State Saniri, because the previous Saniri performance was not optimal, this was due to their lack of knowledge and understanding about the duties and functions and authority of Saniri, so that members of the country's Saniri committed unsavory acts. When asked further to the informants, actions were not good by Saniri before. There was no openness, and they just said there were wrong actions from the previous Saniri Staff, so they had to be replaced. A new paradigm of public administration emerged by formulating a series of tasks that were dated, as well as practices related to the use of specific values and norms in the implementation of public service accountability (Herizal et al., 2020).

The new Saniri management, not all of them are new people, but there are also those from the old Saniri management, including the new Saniri Chairman, who is a member of the old Saniri. From the results of interviews with the new head of the Saniri. He said that learning from yesterday's experience, the Chairperson of Saniri certainly did not want to repeat the failure of the previous State Saniri, so they wanted to work well following the main tasks and functions as outlined in the Central Maluku District Regulation No. 4 of 2006. From the study results, it is not possible to assess the performance of domestic sanitation, and this is because it has not been a year since they have carried out their duties and functions. However, State Saniri is currently drafting a State Regulation that regulates Excavation C from the interview results.

\section{Factors affecting the performance of state Saniri}

In carrying out the duties and functions of Saniri as Partner of the Head of State Government (King) in the administration of Government in Mamala Country, of course, there is hope and desire for Saniri Negeri to be more effective in carrying out its duties and functions correctly. The duties and functions include, among others, accommodating and channeling the aspirations of the community, as executor of supervision of the state revenue and expenditure budget, guardian of customs, and together with the head of the state government establishing state regulations. Saniri Negeri is also expected always to be wise and wise and always put the interests of the community above personal interests, putting the public interest above the interests of the groups and groups it represents.

From the study results, it was found that several factors caused the performance of the Saniri to be not optimal, including, First, the human resources of the national Saniri. If the membership of the saniri from human resources is not yet competent, then the members of the saniri have not been able to carry out their duties and functions correctly. This will result in the weakness of the country's sanitation in responding to all the needs of the people of the Mamala country. In addition, the lack of knowledge and understanding of state saniri also impacts the responsibility to formulate various state regulations. Second, facilities and infrastructure. In supporting the performance of the Saniri institution, the infrastructure is very much needed by Saniri. So far, the Saniri of Mamala country has not had a permanent building for them to work. During this time, they always held meetings at the head of the Saniri house. Apart from this, they also need supporting facilities, in the form of computers, printers, paper, stationery to support the smooth running of their work (Ika \& Donnelly, 2017; Millar \& Doherty, 2016).

\section{National Saniri institution capacity building strategy}

Capacity building here is strengthening the capabilities possessed by each individual (in society), institutions, network systems between individuals and social groups/organizations, and other parties outside the community system to the global level. Capacity building is a process of increasing the ability of individuals, groups, organizations, and other institutions to understand and implement development in a broad sense in a sustainable manner. Meanwhile, according to Wance et al. (2020), the knowledge of the Village Government 
(Pemdes) is still fragile, so a training method for increasing the capacity of the village government in good governance is needed based on the principles of financial governance and development planning.

Morison (Riyadi \& Bratakusumah, 2005), sees capacity development as a process to carry out something, or a series of movements, multi-level change in individuals, groups, organizations, and systems to strengthen the adaptability of individuals and organizations so that they can be responsive. To changes in the existing environment. Katty Sessions (Riyadi \& Bratakusumah, 2005), states that capacity building is generally understood as an effort to assist the government, community, or individuals in developing the skills and skills needed to realize their goals. So far, capacity building is only intended for village/state government officials. Whereas the State Saniri institution, as a partner of the head of the state government, needs to be given capacity strengthening to develop the Saniri institution's human resources. There are several Capacity Building Strategies for State Saniri institutions, including;

1) Strengthening the Capacity of Saniri Institutions

Strengthening the Capacity of Saniri Institutions is more emphasized on: 1) Personal capacity strengthening Strengthening personal capacity puts more emphasis on the individual individuals of the Saniri institution, both as chairman and members of the Saniri, so that they play a more active role in the community carry out their duties and functions. 2) Strengthening the capacity of state sanitary institutions. Strengthening the capacity of the Saniri institution places more emphasis on the people in the Saniri institution where they can work together to carry out their duties, they can share their various understandings about the structure and function of the Saniri institution itself.

2) Development of cooperation network

The Saniri Institution must be able to build partnerships, both with the Mamala State government, with stakeholders at the Mamala State level, and with external parties. In order to be able to carry out the control function on the performance of the state government, as well as invoicing various aspirations from the community, Saniri also feels the need for assistance from relevant agencies in this case from the Central Maluku district government, as well as opening up communication space with academics.

\section{Conclusion}

From the research results, the following conclusions can be drawn: a) In carrying out the duties and functions of the State, Saniri has not been maximized. This is because the saniri has only been carrying out its duties and functions for approximately seven months. Even so, they did their best, among other things, by drafting a state regulation governing Excavation C; b) The factors that affect the performance of Saniri are the human resource factor of the Saniri institution itself and the unavailability of facilities and infrastructure to support work from the Saniri institution; c) There are several strategies used to improve State Saniri, among others. It is strengthening the capacity of the Saniri institution, both individually and institutionally, as well as building cooperation with the Mamala State government partners and stakeholders both at the Mamala State level and from outside.

\section{Acknowledgments}

Our gratitude goes to Universitas Pattimura for providing researchers with the opportunity to obtain Institutional Research Grants from the Faculty of Social and Political Sciences. The Department of Administrative Sciences lecturer has provided input and support so that this research can be completed.

Fretes, J. de, Soasiu, S., \& Suatrat, F. (2022). The urgency of developing the capacity building on Saniri institution. International Journal of Social Sciences and Humanities, 6(1), 23-29. https://doi.org/10.53730/ijssh.v6n1.3064 


\section{References}

Antin, T. M., Constantine, N. A., \& Hunt, G. (2015). Conflicting discourses in qualitative research: The search for divergent data within cases. Field Methods, 27(3), 211-222.

Bengtsson, M. (2016). How to plan and perform a qualitative study using content analysis. NursingPlus Open, 2, 8-14. https://doi.org/10.1016/j.npls.2016.01.001

Biitir, S. B., Nara, B. B., \& Ameyaw, S. (2017). Integrating decentralised land administration systems with traditional land governance institutions in Ghana: Policy and praxis. Land use policy, 68, 402-414. https://doi.org/10.1016/j.landusepol.2017.08.007

Cramb, R. A., \& Wills, I. R. (1990). The role of traditional institutions in rural development: community-based land tenure and government land policy in Sarawak, Malaysia. World Development, 18(3), 347-360. https://doi.org/10.1016/0305-750X(90)90122-E

Geiling, J., Burkle Jr, F. M., Amundson, D., Dominguez-Cherit, G., Gomersall, C. D., Lim, M. L., ... \& Task Force for Mass Critical Care. (2014). Resource-Poor Settings: Infrastructure and Capacity Building. Chest, 146(4), e156S-e167S. https://doi.org/10.1378/chest.14-0744

Herizal, H., Mukhrijal, M., \& Wance, M. (2020). Pendekatan akuntabilitas pelayanan publik dalam mengikuti perubahan paradigma baru administrasi publik. Journal of Governance and Social Policy, 1(1).

Ika, L. A., \& Donnelly, J. (2017). Success conditions for international development capacity building projects. International Journal of Project Management, 35(1), 44-63. https://doi.org/10.1016/j.ijproman.2016.10.005

Kaliky, P. I. ., Wance, M. ., \& Matdoan, M. Y. . (2020). The reality of government communication in hitu lama negeri development planning, Central Maluku Regency . International Research Journal of Management, IT and Social Sciences, 7(6), 153-160. https://doi.org/10.21744/irjmis.v7n6.1031

La Suhu, B., \& Wance, M. (2019). Pemberdayaan Masyarakat Petani Rumput Laut Di Kabupaten Halmahera Selatan (Studi Desa Mano Kecamatan Obi Selatan). JOURNAL OF GOVERNMENT (Kajian Manajemen Pemerintahan dan Otonomi Daerah), 4(2), 156-172.

Marshall, B., Cardon, P., Poddar, A., \& Fontenot, R. (2013). Does sample size matter in qualitative research?: A review of qualitative interviews in IS research. Journal of computer information systems, 54(1), 11-22.

Merino, S. S., \& de los Ríos Carmenado, I. (2012). Capacity building in development projects. Procedia-Social and Behavioral Sciences, 46, 960-967. https://doi.org/10.1016/j.sbspro.2012.05.231

Millar, P., \& Doherty, A. (2016). Capacity building in nonprofit sport organizations: Development of a process model. Sport management review, 19(4), 365-377. https://doi.org/10.1016/j.smr.2016.01.002

Moenir, A. S. (2008). Manajemen pelayanan umum di Indonesia.

Moleong, L. J. (2007). Metode penelitian kualitatif.

Morse, J. M. (2015). Critical analysis of strategies for determining rigor in qualitative inquiry. Qualitative health research, 25(9), 1212-1222.

Percy, W. H., Kostere, K., \& Kostere, S. (2015). Generic qualitative research in psychology. The qualitative report, 20(2), 76-85.

Phillippi, J., \& Lauderdale, J. (2018). A guide to field notes for qualitative research: Context and conversation. Qualitative health research, 28(3), 381-388.

Poudel, D. P. (2019). Migration, forest management and traditional institutions: Acceptance of and resistance to community forestry models in Nepal. Geoforum, 106, 275-286. https://doi.org/10.1016/j.geoforum.2019.09.003

Riyadi, B., \& Bratakusumah, S. (2005). Perencanaan Pembangunan Daerah. Jakarta: PT. Gramedia Pustaka Utama.

Suacana, I. W. G., \& Suaib, E. (2016). Democracy model based on Bali local wisdom values for capacity building of regional governance. International Research Journal of Management, IT and Social Sciences, 3(9), 27-36. Retrieved from https://sloap.org/journals/index.php/irjmis/article/view/411

Tuanaya, W., Tuhumury, J. J., \& Wance, M. (2020). Management Model And Village Fund Allocation During Pandemic Covid-19 In Waiheru Village Ambon Cityindonesia. PalArch's Journal of Archaeology of Egypt/Egyptology, 17(7), 13357-13369.

Wance, M., Muhtar, M., \& Kaliky, P. I. (2020). PKM Penyelenggaraan Pemerintahan Dalam Perencanaan Pembangunan Negeri Hila Kabupaten Maluku Tengah.CARADDE: Jurnal Pengabdian Kepada Masyarakat, 2(2), 229-338. 
Wickham, J. D., Riitters, K. H., Wade, T. G., \& Vogt, P. (2010). A national assessment of green infrastructure and change for the conterminous United States using morphological image processing. Landscape and Urban Planning, 94(3-4), 186-195. https://doi.org/10.1016/j.landurbplan.2009.10.003

Ziphorah, R. M. (2014). Information and communication technology integration: Where to start, infrastructure or capacity building?. Procedia-Social and Behavioral Sciences, 116, 3649-3658.

https://doi.org/10.1016/j.sbspro.2014.01.818

\section{Biography of Authors}

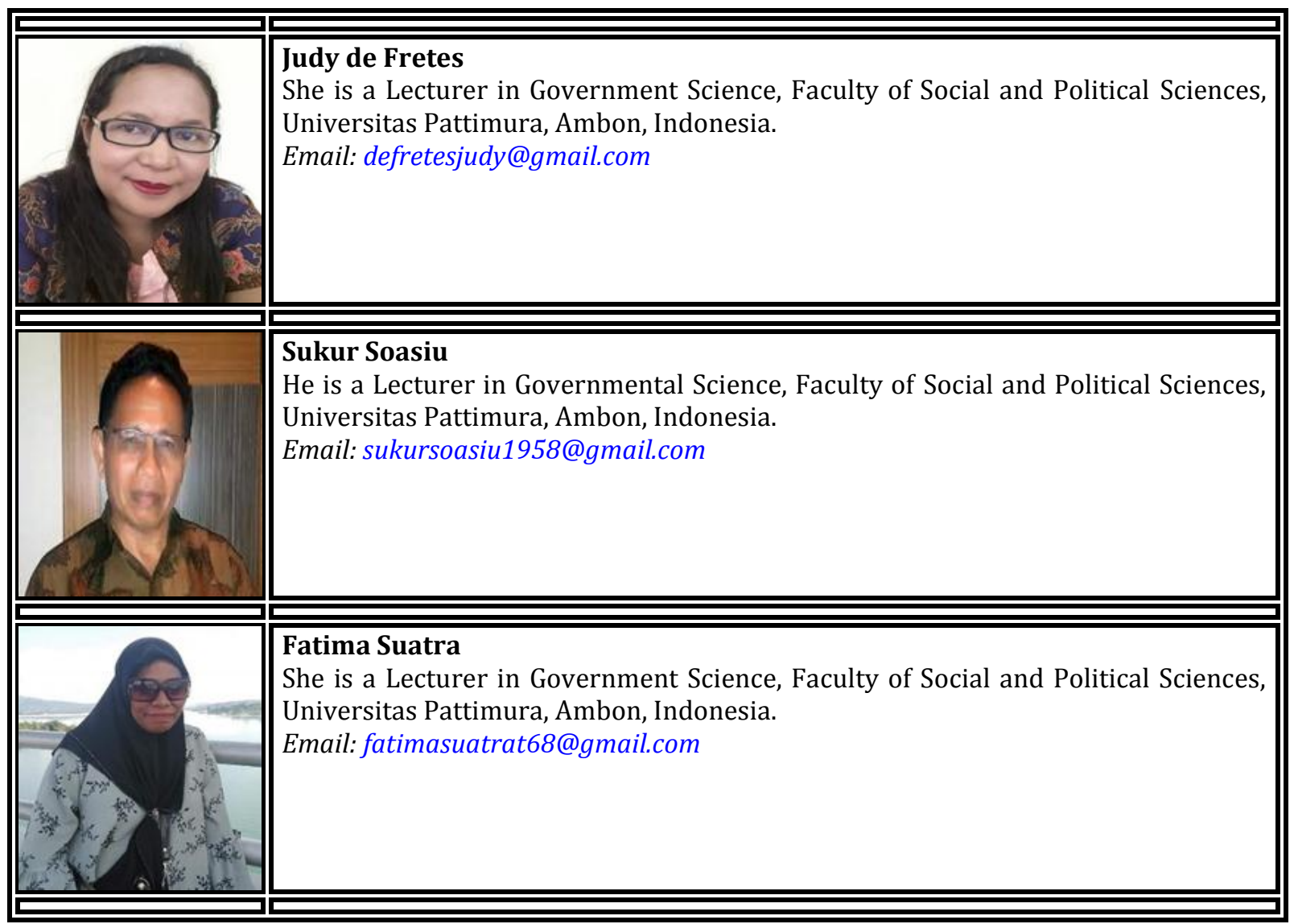

Fretes, J. de, Soasiu, S., \& Suatrat, F. (2022). The urgency of developing the capacity building on Saniri institution. International Journal of Social Sciences and Humanities, 6(1), 23-29. https://doi.org/10.53730/ijssh.v6n1.3064 